\begin{tabular}{|c|c|c|}
\hline & Int.J.Curr.Microbiol.App.Sci (2017) 6(1): 819-833 & \\
\hline FXCEI ENT & $\begin{array}{l}\text { International Journal of Current Microbiology and Applied Sciences } \\
\text { ISSN: 2319-7706 Volume } 6 \text { Number } \mathbf{1} \text { (2017) pp. 819-833 } \\
\text { Journal homepage: http://www.ijcmas.com }\end{array}$ & 89 \\
\hline $\begin{array}{l}\text { EXCELLENT } \\
\text { PUBLISHERS }\end{array}$ & & \\
\hline
\end{tabular}

\title{
Prevalence of Enteropathogenic Escherichia coli in Maize (Zea mays) or Millet (Pennicetum glaucum) Flours and Porridges
}

\author{
D. Kouame N'zebo ${ }^{1 *}$, A. Dadie ${ }^{1}$, O.L. Anin-Atchibri ${ }^{3}$, N. Kouassi ${ }^{2}$ and K.M. Dje ${ }^{1}$ \\ ${ }^{1}$ Department of Food Science and Technology, Laboratory of Biotechnology and Food \\ Microbiology, University of Nangui Abrogoua, 02 BP 801 Abidjan 02, Côte d'Ivoire \\ ${ }^{2}$ Laboratory of Molecular pathology and biotechnology / National Center of Agronomic \\ Research, Abidjan, Côte d'Ivoire, \\ ${ }^{3}$ Department of Food Science and Technology, Laboratory of Nutrition and Food security, \\ University of Nangui Abrogoua, 02 BP 801 Abidjan 02, Côte d'Ivoire \\ *Corresponding author
}

\begin{tabular}{|c|c|}
\hline & A B S T R A C T \\
\hline $\begin{array}{l}\text { Cereal, } \\
\text { Enteropathogenic } \\
\text { Escherichia coli, } \\
\text { flour, porridge, } \\
\text { prevalence. }\end{array}$ & \multirow{3}{*}{$\begin{array}{l}\text { Enteropathogenic Escherichia coli (EPEC) was a leading cause of infantile diarrhea in } \\
\text { many countries. But this bacteria had never research in flours and porridges consume by } \\
\text { infant in Côte d'Ivoire. The aim of this study was to determine the prevalence of EPEC in } \\
\text { maize and millet flours and porridges made traditionally. EPEC were research in } 996 \\
\text { samples of traditional cereals products, with } 404 \text { flours and } 592 \text { porridges. These products } \\
\text { were taken in five municipalities of Abidjan. The strains were characterized by detection } \\
\text { of virulence factors and phylogenetic method. The results revealed that the prevalence of } \\
\text { EPEC was } 4.1 \% \text { in millet porridge and } 3.4 \% \text { in maize porridge. This prevalence was } 6.4 \% \\
\text { and } 5.4 \% \text { respectively in millet and maize flours. Most of EPEC; } 68.2 \% \text { isolated was } \\
\text { atypical. EPEC detected belong to phylogenetic group A ( } 47.2 \%) \text {, D }(28.3 \%) \text {, B1 }(13.2 \%) \\
\text { and B2 }(11.3 \%) \text {. In short, traditional flours and porridges from maize and millet used in } \\
\text { infant food were risk factors by EPEC contamination, which was potentially pathogen for } \\
\text { children. }\end{array}$} \\
\hline Article Info & \\
\hline $\begin{array}{l}\text { Accepted: } \\
22 \text { December } 2016 \\
\text { Available Online: } \\
\text { 10 January } 2017\end{array}$ & \\
\hline
\end{tabular}

\section{Introduction}

Nowadays, foods based on completes cereals are increasingly recognized as health and wellness factor, as well as of interest because of the different nutrients they contain (carbohydrates, proteins, lipids, vitamins, and minerals) as related by Wrigley (2004); Fletcher (2004); Corsetti and Settanni (2007). Cereals go into the formulation of complementary foods throughout the world (FAO, 2007; Kohajdová and Karovičová, 2007). If cereals are the staple food of the population, it should be noted that local production does not satisfy the consumption requirement. According to PAM (2008), cereal products accounted for $56 \%$ of food imports, in others words 1.5 million tonnes. Throughout Africa, (Abegaz et al., 2002; Traore et al., 2003, Glidja, 2004; Tou, 2007; Elenga et al., 2009; Amankwah et al., 2009; Nout, 2009; Jideani, 2012; Olorode et al., 2013), innstant flour porridges are prepared and used as complementary foods during the weaning or post-weaning period for children 
over 6 months (Tou, 2007). Industrial cerealbased flours used as complementary foods are those recommended by international bodies in rural and urban areas for their guaranteed nutritional and health qualities (Trèche, 2002; Hervé et Mouquet-Rivier, 2004). However, these foods, although rich in nutrients (Trèche, 2002; Nguyen, 2008), are most often imported and are difficult to access for the majority of the population because of their high cost (TPA, 1998).

The alternative for some developing countries is the formulation of complementary foods or porridges made from simple, fermented, or enriched cereal flours and made traditionally (Tou, 2007, Oumarou et al., 2012). But the sanitary quality of traditional flours and porridge is often questioned. Thus, pathogenic bacteria such as Salmonella, Campylobacter, Listeria and Shigella have been isolated from porridges based on cereal-flour (Gadaga et al., 2004). It was the same for EPEC, Bacillus cereus and E. coli isolated from children's meals made from sorghum and complementary foods (Gadaga et al., 2004, Islam et al., 2012). In addition, Oluwafemi and Nnanna Ibeh (2011) have found aflatoxins in foods for the consumption of children in Nigeria.

Among these germs, enteropathogenic E. coli (EPEC) has a prominent position in the etiology of gastroenteritis in children under five years of age (Yousef et al., 2007). Indeed, the pathovars of $E$. coli persist and develop well in various foods and especially in traditionally formulated foods (Berche, 2001). EPEC are raged in Latin America (Adriana et al., 2009), Asia (Ogata et al., 2002), Europe (Afset et al. 2004) and Africa (Rappelli et al., 2005).

In Côte d'Ivoire, the studies of Brou et al. $(2009,2013)$ and Soro-yao et al. $(2013,2014)$ demonstrated the use of cereal meal-based porridge in the same context and in several forms. The process of flour and porridge production remains partially or wholly traditional, while the instant flours recommended by the international authorities are industrial production. As a result, the health status of traditionally produced products is poorly understood.

In addition, recent studies (Dadie et al., 2010, Dadie, 2013) in Côte d'Ivoire showed the presence of EPECs in cooked minced meat, raw milk, dairy products and their involvement in infant diarrhea (Dadie et al., 2014). In this context, the evaluation and the risk management of EPEC infection related to the consumption of complementary foods is urgently necessity.

The objective of the study was to determine the rate of EPEC contamination of flours and local complement porridges by identifying the virulence genes as well as the phylogenetic grouping of EPECs.

\section{Materials and Methods}

\section{Study area and selection criteria}

The material of study was consisted of millet (Pennisetum glaucum) and maize (Zea mays) flours and porridges. The flours and porridge concerned are those intended for human consumption, in particular in infant food. They are sold near certain schools, markets or other public places in the municipalities of Abobo, Adjamé, Attécoubé, Koumassi and Yopougon. These municipalities were chosen for their popular character and especially for the multiplicity of flours and porridge selling places. The sales sites selected are those located near the schools attended by children and those located near certain markets.

\section{Flours and porridges samples}

A sample of porridge has been setting up about $300 \mathrm{ml}$ of porridge packaged in a non- 
food plastic material. On the other hand, a sample of flour was made up of $200 \mathrm{~g}$ of flour. Flours were taken from a set of flours packaged in bulk in plastic or aluminum bowls. The removal of the porridge was carried out by the vendors who used a ladle which they introduced into non-food plastic. For flours, the sellers were used a plastic cup or sometimes theirs hands to pick up the flours that was packed in paper. Immediately after collection, samples were chilled in an ice cooler box at $4{ }^{\circ} \mathrm{C}$ and transported to the laboratory for analysis within $2 \mathrm{~h}$ after sampling.

\section{Identification of Escherichia coli strains}

The identification process was performed based on the standard biochemical tests. The oxidase negative Gram negative bacilli were identified as $E$. coli based upon the following test reactions; acid on acid reaction with gas and no $\mathrm{H}_{2} \mathrm{~S}$ production on Kligler iron agar, catalase positive, indole positive, citrate negative, methyl-red positive, urease negative, and Voges-Proskauer negative (Mahon et al. 2007)

\section{Detection of EPEC by PCR}

All strains were examined by polymerase chain reaction (PCR) with the specific primers for the presence of the virulence genes; eaeA, bfpA, stx, Prototype EPEC strain 2348/69 (serotype O127: H6), which expressed intimin, BFP, and EAF and E coli EDL933 (stx+) strain was used as positive control in PCR assays, and E coli HB101 was included in the experiment as a negative control.

PCR assays were performed using the protocol described by Beij et al. (1991) for detection of uidA gene and Yatsuyanagi et al. (2002) for detection of the following virulence genes: eaeA (structural gene for intimin of EHEC and EPEC), bfpA (structural gene for the bundle-forming pilus of EPEC).The minimum criteria for determination of EPEC were defined as follows: the absence of stx 1 and stx 2 for EHEC (the presence of stx 1 and stx 2 and additional presence of eaeA confirmed the detection of a typical EHEC isolate), the presence of $b f p \mathrm{~A}$ and eaeA for typical EPEC (but the presence of only eaeA for atypical EPEC).

Template DNA was extracted from whole organisms by boiling. Bacteria were harvested from an overnight broth culture, suspended in $500 \mathrm{ml}$ sterile deionized water (Analar NORMAPUR, PROLABO) and boiled at 100 ${ }^{\circ} \mathrm{C}$ for $10 \mathrm{~min}$ and then centrifuged at 12000 $\mathrm{g}$ for $15 \mathrm{~min}$ to pellet the cell debris (Theron et al., 2000; Momba et al., 2006). A $5 \mathrm{ml}$ aliquot of supernatant was used for PCR. The oligonucleotide primers used in this study are listed in Table 1.

Single PCR: It was used to detect gene uidA. PCR mixtures with a final volume of $25 \mu \mathrm{L}$ consisted of $10.73 \mu \mathrm{L}$ sterile deionized water (Analar NORMAPUR, PROLABO), $5 \mu \mathrm{L}$ template DNA, $1.25 \mathrm{mM}$ each dNTP $(4 \mu \mathrm{L})$; $0.4 \mu \mathrm{L}$ each primer; $2.5 \mu \mathrm{L}$ template $10 \mathrm{X}$ (EUROBIO), $\quad 1.5 \mathrm{mM} \quad \mathrm{MgCl}_{2} \quad(25 \mathrm{mM})$ (EUROBIO) and $0.5 \mu \mathrm{L}$ Taq DNA polymerase (5 UI/ $\mu \mathrm{L}$; EUROBIOTAQ ADN POLYMERASE).

Mutiplex PCR: It was used to detect gene stx1, stx2, eaeA and bfpA from E. coli uid $\mathrm{A}^{+}$. PCR mixtures with a final volume of $25 \mu \mathrm{L}$ consisted of $9.05 \mu \mathrm{L}$ sterile deionized water (Analar NORMAPUR, PROLABO), $5 \mu \mathrm{L}$ template DNA, $1.25 \mathrm{mM}$ each dNTP $(4 \mu \mathrm{L})$ (SIGMA); $0.8 \mu \mathrm{L}$ each primer; $2.5 \mu \mathrm{L}$ template $10 \mathrm{X}$ (EUROBIO), $1.5 \mathrm{mM} \mathrm{MgCl}_{2}$ (25mM) (EUROBIO) and $0.25 \mu \mathrm{L}$ Taq DNA polymerase (5 UI/ $\mu \mathrm{L}$; EUROBIOTAQ ADN POLYMERASE). 
Each PCR was performed using thermocycleur type Biometra UNO II, Thermoblock version 3.300, biotron 1998, série 1712243 . The reaction was started with a 3 min denaturation step at $94{ }^{\circ} \mathrm{C}$. The temperature cycles consisted of $1 \mathrm{~min}$ at 94 ${ }^{\circ} \mathrm{C}$, followed by $1 \mathrm{~min}$ at $56{ }^{\circ} \mathrm{C}$ and $1 \mathrm{~min} 30$ $\mathrm{s}$ at $72^{\circ} \mathrm{C}$. Each cycle was repeated 30 times, and the final cycle was followed by incubation of the reaction mixture for $6 \mathrm{~min}$ at $72{ }^{\circ} \mathrm{C}$. The amplified DNA was separated by submarine gel electrophoresis in $1.5 \%$ agarose, stained with ethidium bromide and visualized under UV transillumination.

\section{Determination of phylogenetic groups}

A triplex PCR were performed using the protocol described by Clermont et al. (2000) for detection of the genes Chua yjaA and TSPE4.C2 fragment. The oligonucleotide primers used in the phylogenetic groups study are listed in Table 1.

PCR mixtures with a final volume of $25 \mu \mathrm{L}$ consisted of, $5 \mu \mathrm{L}$ template DNA, $1.5 \mathrm{mM}$ each dNTP; $25 \mathrm{mM} \mathrm{MgCl}_{2} 20$ pmol each primer; a bufffer 10X (EUROBIO), and Taq DNA polymerase. The reaction was started with a 4 min denaturation step at $94{ }^{\circ} \mathrm{C}$. The temperature cycles consisted of $20 \mathrm{~s}$ at $94{ }^{\circ} \mathrm{C}$, followed by $15 \mathrm{~s}$ at $59{ }^{\circ} \mathrm{C}$ and $30 \mathrm{~s}$ at $72^{\circ} \mathrm{C}$. Each cycle was repeated 30 times, and the final cycle was followed by incubation of the reaction mixture for $6 \mathrm{~min}$ at $72{ }^{\circ} \mathrm{C}$. The amplified DNA was separated by submarine gel electrophoresis in $1.5 \%$ agarose, stained with ethidium bromide and visualized under UV transillumination.

\section{Statistical analysis}

The data were analyzed with SSPS version 20.0 software (SPSS). A $\chi^{2}$ test was used to determine the statistical significance of the data. A P value of 0.05 was considered significant.

\section{Results and Discussion}

\section{Virulence factors for $E$ coli strains}

All E. coli strains study with PCR were uidA+. Any stx (stxl et stx2) gene have been shown in this study. All E coli strains were identified based on the detection of the $e a e \mathrm{~A}+, b f p \mathrm{~A}-$ or eaeA-, $b f p \mathrm{~A}+$ profiles and the absence of stx gene as atypical EPEC.

Electrophoretic analysis of E. coli isolates has been showed in figure 1. Based on the differences in the number of fragments, the isolates showed 2 differentes bands. These bands showed the presence of EPEC.

All strains showed a positive reaction with one or more primers for eae $\mathrm{A}(367 \mathrm{pb})$ and bfpA (324 pb) genes. On the basis of these positive reactions, two different combinations of virulence factor genes were identified: $e a e \mathrm{~A}+, b f p \mathrm{~A}-$, stx-, eae $\mathrm{A}-, b f p \mathrm{~A}+, s t x-$. These profiles were recognized as the definitive combination for atypical EPEC. And eaeAt, $b f p \mathrm{~A}+$, stx- was recognized as the definitive combination for typical EPEC. The distribution of these virulence genes according to the PCR types identified is shown in Table II.

Out of the 46 strains, $22(47.8 \%)$ showed the characteristic atypical EPEC combination of eae $\mathrm{A}+$, bfp $\mathrm{A}-$, stx-, 7 (15.2\%) eae $\mathrm{A}-$, bfp $\mathrm{A}+$, stx-, and $17(37 \%)$ two profile combinations. In flours, combination of eaeA+, bfpA-, stxis $12(50 \%), e a e \mathrm{~A}-$, bfp $\mathrm{A}+, s t x-$ is $2(8.3 \%)$ and the two profiles combination were 10 $(41.7 \%)$. But in porridges, these combination were $10(45.5 \%)$ for eaeA+, bfpA-, stx-, 5 $(22.7 \%)$ for eaeA-, bfp $\mathrm{A}+$, stx- and $7(31.8 \%)$ for two profiles combination.

\section{Prevalence of EPEC}

A prevalence of 3.7\% of EPEC were found in porridges and $5.9 \%$ in flours. There was 
statistically significant correlation regarding the prevalence of EPEC (4.6\%) isolates in relation to flours and porridges $(\mathrm{p}<0.05)$. EPEC strains were mostly isolated in millet product than maize product. Thus, in porridge, $12(4.1 \%)$ EPEC were detected in millet porridge and $13(6.4 \%)$ were also detected in millet flour (Table III).

\section{Compliant rate}

The virulence of EPEC strains for children was very study. So the presence of EPEC in children food was considered that this food is not safety for them. The analysis of sample considering the presence of EPEC showed 950 samples out of $996(95.4 \%)$ were noncompliant according of normative values. A rate of $4.6 \%$ of products is non-compliant. However, there was no significant difference $(p \geq 0.05)$ between the proportions of compliant products. In addition, noncompliance was higher in millet flours with $6.4 \%$ (Table IV).

\section{Typical and atypical EPEC}

Table V showed all of EPEC detected; it showed that 22 EPEC were found in porridges and 24 in flours. Among the 46 EPEC isolated in flours and porridges, $29(63 \%)$ were atypical EPEC (aEPEC) with 15 (68.2\%) aEPEC in porridges and $14(58.3 \%)$ aEPEC in flours. Otherwise, 17 (37\%) of EPEC were typical EPEC (tEPEC) with $07 \quad(31.8 \%)$ aEPEC in porridges and $10(41.7 \%)$ aEPEC in flours.

\section{EPEC phylogenetic group}

Electrophoretic analysis of enteropathogenic E. coli phylogenetic group has been showed in figure 2. Tis figure shows different bands of sizes $279 \mathrm{bp}, 211 \mathrm{bp}$ and $152 \mathrm{bp}$. These sizes correspond respectively to the ChuA, Yja and Tspec gene.
As shown in Table VI, EPEC strains are phylogenic group A (47.2\%). The strains of group D represent $28.3 \%$ of all EPEC pathovars. Out of the 19 pathotypes in the porridges, $9(47.4 \%)$ EPEC were to the phylogenic group A and were the most frequent. Five (5) pathotypes were to phylogenic group D $(26.3 \%)$ and 3 to group B1 $(15.8 \%)$. E. coli strains belonging to the phylogenic group B2 (10.5\%) are the weakest represented. Otherwise, in flours, $16(47.1 \%)$ strains were to group A and it is the group which contains more pathotypes. It was followed by group D (29.4\%).

The results presented here showed that enteropathogenic $E$. coli were found in a wide range in porridges and flour prepared at home and sold near certain schools, markets or other public places. Our study shows a prevalence of $4.6 \%$ in both flours and porridges but, EPEC were most isolated in flours than in porridges $(\mathrm{p}<0.05)$. The results were similar to the report of Norazah et al. (1998) in Malaysia.

Many studies lead in flours have shown presence of Escherichia coli (Sperber, 2007) and others such as E. coli, coliforms, Bacillus cereus, Bacillus spp (Berghofer et al. 2003) and many other microorganisms in flours in Australia to a lesser extent. Other studies have shown the absence of pathogenic germs in flours (Olorunfemi et al., 2005) and in the porridges (Soro-yao et al., 2013). In Africa, cereals flours are used for porridges and porridges are used as traditional African weaning food. The flour (maize and millet) was the most contaminated commodity in the products. In their study of pathogenic E. coli in traditional African weaning food, Nyatoti et al. (1997) found E. coli in $36 \%$ of the food samples used for weaning foods, most of which are prepared from maize flour. Kunene et al. (1999) found an E. coli incidence of $53 \%$ with a range of $3.20-5.02 \log 10 \mathrm{CFU} / \mathrm{g}$ 
in sorghum flour and fermented sorghum porridge, commodities that have similar characteristics to maize flour. Home-made street-vended foods have also been reported to contain E. coli incidence of between 7 and 32\% (Cardinale et al., 2005; Hanashiro et al., 2005). There was a high overall incidence of enteropathogenic E. coli in this study $(3.7 \%$ of the porridge samples and $5.9 \%$ of the flour samples), with the highest incidence in millet flour (6.4\%) and millet porridge (4.1\%). Previous studies carried out in Zimbabwe have reported finding pathogenic E. coli (EPEC) in $16 \%$ of all food samples (Simango et al., 1992) while Nyatoti et al. (1997) detected pathogenic strains of E. coli in 15\% of their food samples.

Also, pathogenic bacteria of Salmonella, Campylobacter, Listeria and Shigella have been isolated from various infant foods, including gruels based cereal-flour (Gadaga et $a l ., 2004)$. The same was true for EPEC, Bacillus cereus and E. coli isolated from children's meals made from sorghum and complementary foods (Kunene et al., 1999, Islam et al., 2012). Furthermore, Motarjemi et al. (1993) detected Aeromonas Spp, Staphylococcus aureus, Bacillus cereus, Salmonella spp. and Vibrio cholerae in children's porridge from maize in Ghana.

Hygiene during handling and cooking food is very important. Human beings represent the largest contamination sources of food. Health and personal hygienic knowledge of the street food vendors surveyed are also important. The contamination of flour and porridge could be explained by the fact that, according to many authors pathogenic E. coli can survive on the hands, tools at large number and contaminated food (Moore et al., 2003; Dawson et al., 2006; Taulo et al., 2009).

According to WHO (1989), hand-washing is very important because the hands are considered the most important vehicle for transfer of micro-organisms from faeces, nose, skin and other parts of the body into food. Studies in Epidemiology have further confirmed that bacteria such as Salmonella typhi, Escherichia coli can survive for varying periods on the fingers and other parts of the body (Pether and Gilbert, 1971). Mensah et al. (2002) reported in a study in Accra that out of 511 street food items examined in Accra, 69.7\% contained mesophilic bacteria and $33.7 \%$ contained Enterobacteriaceae. Also in Côte d'Ivoire Dadié et al. (2010, 2013 , 2014) reported the presence of EPEC and other Escherichia coli in food and their implication in infant diarrheara. From these studies, it is evident that flour and porridges which are manipulated by the hand contain EPEC.

Domestic practices of food handling and preparation are one of the numbers of reasons that explain the increasing incidence of gastrointestinal infection associated with domestic environments (Scott et al., 1982, Daniels, 1998; Beumer and Kusumaningram, 2003). The study has demonstrated that the incidence of EPEC was high in manipulated food.

Thus, this contamination by EPEC could also be justified by environment as shown in Ghana during studies of Feglo and Sakyi (2012).

On the other hand, the contamination of the porridge sold near certain schools, markets or other public places and traditional flours sold in open markets, analyzed during this study, could be favored by an exposure temperature such as temperatures between $20{ }^{\circ} \mathrm{C}$. and 40 ${ }^{\circ} \mathrm{C}$ which are favorable to the proliferation of EPEC. However, the studies of Yeboah-Manu et al. (2010) have shown that this contamination is due to excessive handling of food products. In addition, the study of WHO 
(2003) showed that non-protection against aerosols is a cause of EPEC contamination.

Temperature has an impact on the transmission of pathogenic germs. Taulo et al. (2009) showed in their study that samples collected at temperatures less than $30{ }^{\circ} \mathrm{C}$ contained significantly more strains of Escherichia coli and Staphylococcus aureus followed by samples collected at temperatures between $30{ }^{\circ} \mathrm{C}$ and $40{ }^{\circ} \mathrm{C}$ and finally Samples collected at temperatures above $40^{\circ} \mathrm{C}$ which contained fewer germs.

The presence of EPEC in food is associated with contamination that has been directly introduced into the food by food handlers through coughing and sneezing as well as storage of food at high temperature (Kaneko et al., 1999; Sandel and McKillip, 2004). In this study, it was observed that most porridge was prepared in advance and stored at ambient temperature for $1-4 \mathrm{~h}$ before finishing selling and this practice could have allowed the pathogens to grow to large numbers. The high number of pathogens and the ambient food storage temperature reported in some households may be a contributing factor with regards to EPEC food intoxication in children population.

One of the major factors contributing to the deterioration of the microbiological quality of foods (street) in developing countries is their maintenance at room temperature for several hours of sale. This explains the frequent association of street foods with gastroenteritis disorders (Barro et al., 2007).

Table.1 Primers used

\begin{tabular}{|c|c|c|c|}
\hline Genes & Primers & $\begin{array}{l}\text { Size } \\
(\mathrm{pb})\end{array}$ & $\begin{array}{l}\text { References/ } \\
\text { Gen bank } \\
\text { EMBL, no }\end{array}$ \\
\hline $\operatorname{uid} \mathrm{A}$ & $\begin{array}{l}\text { UAL : 5' AAA ACG GCA AGA AAA AGC AG -3', } \\
\text { UAR : 5'ACG CGT GGT TAC AGT CTT GCG -3' }\end{array}$ & 147 & $\begin{array}{l}\text { Beij et al., } \\
1991\end{array}$ \\
\hline$e a e A$ & $\begin{array}{l}\text { Eaef 5'-CACACGAATAAACTGACTAAAATG-3' } \\
\text { Eaer 5'-AAAAACGCTGACCCGCACCTAAAT-3' }\end{array}$ & 367 & $\begin{array}{l}\text { Yatsuyanagi } \\
\text { et al., } 2002\end{array}$ \\
\hline bfpA & $\begin{array}{l}\text { Y bfp fp-5'-AATGGTGCTTGCGCTTGCTGC-3' } \\
\text { Y bfp bp-5'-GCCGCTTTATCCAACCTGGTA-3' }\end{array}$ & 324 & $\begin{array}{l}\text { Yatsuyanagi } \\
\text { et al., } 2002\end{array}$ \\
\hline stx 1 & $\begin{array}{l}\text { stx1f-5'-GAAGAGTCCGTGGGATTACG-3', } \\
\text { stx1r-5'-AGCGATGCAGCTATTAATAA-3' }\end{array}$ & 130 & AF461172 \\
\hline stx 2 & $\begin{array}{l}\text { stx2-5'-ACCGTTTTTCAGATTTTACACATA-3' } \\
\text { stx2-5'TACACAGGAGCAGTTTCAGACAGT-3' }\end{array}$ & 298 & AY143337 \\
\hline ChuA & $\begin{array}{l}\text { ChuA.1 -5'-GACGAACCA ACGGTCAGGAT-3' } \\
\text { ChuA.2 5'-TGCCGCCAGTACCAAAGACA-3' }\end{array}$ & 279 & \\
\hline$Y j a A$ & $\begin{array}{l}\text { YjaA.1- 5'-TGAAGTGTCAGGAGACGCTG-3' } \\
\text { YjaA.2 5'-ATGGAGAATGCGTTCCTCAAC-3' }\end{array}$ & 211 & $\begin{array}{l}\text { Clermont et } \\
\text { al., } 2000\end{array}$ \\
\hline TspE4C2 & $\begin{array}{l}\text { TspE4C2.1.5'-GAGTAATGTCGGGGCATTCA-3' } \\
\text { TspE4C2.2 5'-CGCGCCAACAAAGTATTACG-3 }\end{array}$ & 152 & \\
\hline $\begin{array}{l}\text { eaeA }: 1 \\
\text { bfpA }: \mathrm{l} \\
\text { stx } 1: \text { st } \\
\text { stx } 2: \text { si }\end{array}$ & $\begin{array}{l}\text { oli attaching-effacing } \\
\text { dle-forming pilus } \\
\text { toxin } 1 \\
\text { toxin } 2\end{array}$ & & \\
\hline
\end{tabular}


Int.J.Curr.Microbiol.App.Sci (2017) 6(1): 819-833

Table.2 Distribution of virulence genes

\begin{tabular}{|c|c|c|c|c|c|}
\hline \multirow[b]{2}{*}{$\begin{array}{l}\text { Virulence } \\
\text { genes }\end{array}$} & \multicolumn{2}{|c|}{ Porridges } & \multicolumn{2}{|r|}{ Flour } & \multirow[b]{2}{*}{$\begin{array}{l}\text { Total } \\
(\%)\end{array}$} \\
\hline & Presence & Frequency $(\%)$ & Presence & Frequency $(\%)$ & \\
\hline eaeAt & + & 45.5 & + & 50 & $22(47.8$ \\
\hline bfp $A+$ & + & 22.7 & + & 8.3 & $7(15.2)$ \\
\hline$E a e^{+}-b f p^{+}$ & + & 31.8 & + & 41.7 & $17(37)$ \\
\hline Stx ${ }^{+}$ & 0 & 0 & 0 & 0 & 0 \\
\hline Total & 22 & 100 & 24 & 100 & $46(100)$ \\
\hline
\end{tabular}

Eae: E. coli attaching-effacing

$B f p$ : bundle-forming pilus

Table.3 Prevalence of EPEC

\begin{tabular}{cccc}
\hline Type of food & $\begin{array}{c}\text { Samples } \\
\text { (Effective) }\end{array}$ & \multicolumn{2}{c}{ EPEC } \\
\cline { 3 - 4 } & & Effective & Prevalence (\%) \\
\hline Porridge of millet & 296 & 12 & 4.1 \\
Porridge of maize & 296 & 10 & 3.4 \\
Total & 592 & 22 & 3.7 \\
\hline Flour of millet & 202 & 13 & 6.4 \\
Flour of maize & 202 & 11 & 5.4 \\
$\quad$ Total & 404 & 24 & 5.9 \\
\hline General Total & $\mathbf{9 9 6}$ & $\mathbf{4 6}$ & $\mathbf{4 . 6}$ \\
\hline
\end{tabular}

Table.4 Compliant rate of analyzed product following the presence of EPEC

\begin{tabular}{cccc}
\hline Type of food & Samples & \multicolumn{2}{c}{ Food product qualities } \\
\cline { 2 - 4 } & & Conforme & Non conforme \\
\hline Porridge of millet & 296 & $284(95.9 \%)$ & $12(4.1 \%)$ \\
Porridge of maize & 296 & $286(96.6 \%)$ & $10(3.4 \%)$ \\
Flour of millet & 202 & $189(93.6 \%)$ & $13(6.4 \%)$ \\
Flour of maize & 202 & $191(94.6 \%)$ & $11(5.4 \%)$ \\
Total & 996 & $950(95.4 \%)$ & $46(4.6 \%)$ \\
\hline
\end{tabular}

Table.5 Distribution of typical and atypical EPEC

\begin{tabular}{llll}
\hline EPEC & $\begin{array}{l}\text { Porridges } \\
\mathbf{N}(\boldsymbol{\%})\end{array}$ & $\begin{array}{l}\text { Flours } \\
\mathbf{N}(\boldsymbol{\%})\end{array}$ & $\begin{array}{l}\text { Total } \\
(\boldsymbol{\%})\end{array}$ \\
\hline Typicals & $7(31.8 \%)$ & $10(41.7 \%)$ & $17(37 \%)$ \\
Atypicals & $15(68.2 \%)$ & $14(58.3 \%)$ & $29(63 \%)$ \\
Total & $22(100 \%)$ & $24(100 \%)$ & $46(100 \%)$ \\
\hline
\end{tabular}


Table.6 Distribution of EPEC following the phylogenetic group

\begin{tabular}{lllll}
\hline Origin & Group A & Group B1 & Group D & Group B2 \\
\hline Porridge of millet & 5 & 2 & 3 & 1 \\
Porridge of maize & 4 & 1 & 2 & 1 \\
Flour of millet & 7 & 2 & 4 & 2 \\
Flour of maize & 9 & 2 & 6 & 2 \\
Total (\%) & $25(47.2 \%)$ & $07(13.2 \%)$ & $15(28.3 \%)$ & $6(11.3 \%)$ \\
\hline
\end{tabular}

Fig.1 Multiplex PCR of virulence genes in EPEC isolates from porridges and flour samples. Lane 1, 50 à $1000 \mathrm{pb}$ molecular weight marker in base pairs; lane 2, positive control; lane 11, negative control and lane 3 to lane 10, PCR products obtained with DNA of EPEC isolates

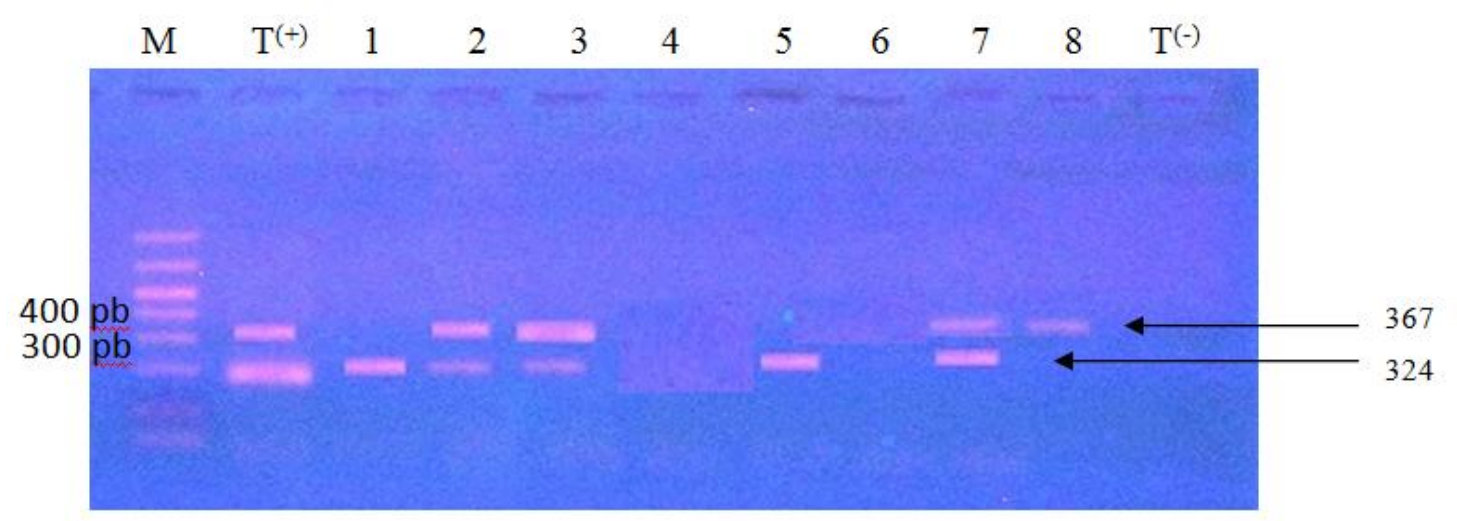

Fig.2 PCR products for phylogenetic group. Lane 1, 50 à 1000 pb molecular weight marker in base pairs; lane 2, positive control; lane 14, negative control and lane 3 to lane 13, PCR products obtained with DNA of EPEC isolates for phylogenetic group

$\begin{array}{llllllllllllll}\mathrm{M}^{(+)} & 1 & 2 & 3 & 4 & 5 & 6 & 7 & 8 & 9 & 10 & 11 & \mathrm{~T}^{(-)}\end{array}$

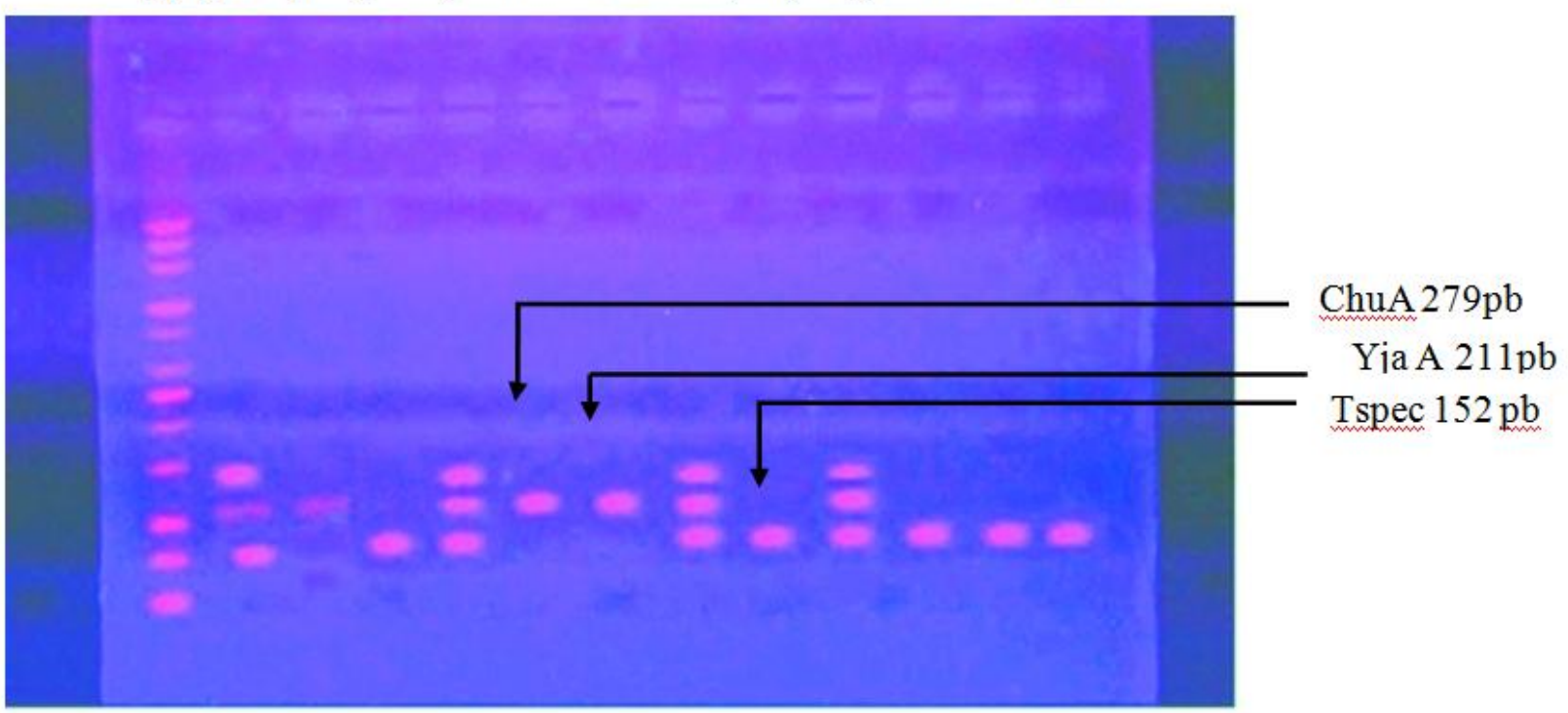


The study showed that there was no significant difference between typical and atypical EPECs ( $p>0.05)$. The typical EPEC rate obtained may be due to the difficulty of detecting the $b f p$ gene, which is controlled by the plasmid EAF and which according to Nataro and Kaper (1998) would only be expressed if the EPECs were not stressed during cultivation.

According to the TPA (1998) standard, more than half of the porridges and flours analyzed are non-compliant. This result can be

explained by the lack of formal surveillance for food prepared and sold on public roads and open markets. Barro et al. (2002) considered that this situation could directly threaten the health of consumers.

Clermont et al. (2000) developed a simple and rapid method (triplex), allowing the classification of pathovars into 4 phylogenetic groups. The application of this technique to the strains gives a diversified phylogenetic distribution, with the majority $(47.2 \%)$ of the pathovars belonging to group $A$. The pathovars of group B2 represent $11.3 \%$ and those of the group D, 28.3\%. The distribution obtained during our study is different from that obtained, following an analysis of 64 strains, by Clermont et al. (2000) who found $58 \%$ of $\mathrm{B} 2,18.7 \%$ of $\mathrm{A}$ and $17.1 \%$ of $\mathrm{D}$. This difference with our results could be due to the fact that Clermont worked on human strains and it is established that most potentially pathogenic extra-intestinal strains belong to group B2 and to a lesser extent group D (Bonacorsi et al., 2000).

In conclusion, the detection of pathogenic $E$. coli in flours and in porridge sold and consumed by children shows that they are sources of pathogens. These germs being etiologic agents of human diarrhea, rules of hygiene must be applied to ensure the safety of porridges and child consumers.

\section{References}

Abegaz, K., Fekadu, B., Thor, L., and Judith, A., N., 2002. Parameters of processing and microbial changes during fermentation of borde, a traditional Ethiopian beverage. The Journal of Food Technology in Africa, 7(3): 85-92.

Adriana, H., R-M., Tania, A., T., G., Monica, A., M., V., Kinue, I., and Lucia, M., T., 2009. Molecular typing and virulence of enteroaggregative Escherichia coli strains isolated from children with and without diarrhoea in Rio de Janeiro city, Brazil. Journal of Medical Microbiology. 58: 414-422

Afset, J., E., Bevanger, L., Romundstad, P., and Bergh, K., 2004. Association of atypical enteropathogenic Escherichia coli (EPEC) with prolonged diarrhoea. Journal of Medical Microbiology 53: 1137-44.

Amankwah, E., A., Barimah, J., Acheampong, R., Addai, L., O., and Nnaji, C., O., 2009. Effect of Fermentation and Malting on the Viscosity of Maize-Soyabean Weaning Blends. Pakistan Journal of Nutrition 8 (10): 1671-1675.

Barro, N., Ouattara, C., A., T., Nikiema, P., Ouattara, A., S., and Traore, A., S., 2002. Evaluation de la qualité microbiologique de quelques aliments de rue dans la ville de Ouagadougou au Burkina Faso. Cahiers santé. 12 (4):369-374.

Barro, N., Ousmane, O., Bello, A., R., Philippe, A., N., André, J., I., Ouattara, A., S., Ouattara, C., A., T., and Traoré, A., S., 2007. L'impact de la température de vente sur l'altération de la qualité microbiologique de quelques aliments de rue à Ouagadougou (BURKINA FASO).

Beij, A., K., DiCesare, J., L., Haff, L., and Atlas, R., M., 1991. Detection of 
Escherichia coli and Shigella spp. in water by using the polymerase chain reaction and gene probes for uid. Applied and Environmental Microbiology, 57:1013-1017

Berche, P., 2001. L'émergence de nouveaux risques infectieux d'origine alimentaire. Dossier: Pathologies émergentes (journée nationale de la SBC, Paris, 24 Novembre 2000. Annales de Biologie Clinique, 59 (5): 585-91.

Berghofera, Lana, K., Hockinga, Ailsa, D., Miskellyb, Di, Jansson, Edward, 2003. Microbiology of wheat and flour milling in Australia. International Journal of Food Microbiology 85: $137-$ 149

Beumer, R., R., Kusumaningram, H., 2003. Kitchen hygiene in daily life. International Journal of Biodeterioration and Biodegradation 51, 299-302.

Bonacorsi, S., P., Clermont, O., and Tinsley, C., 2000. Identification of the Escherichia coli chromosome specific for neonatal meningitis associated strains. Infectious and Immunity, 68: 2096-2101.

Brou, K., Kouadio, E., N'Guessan, J., P., Djue, E., A., Kouame, S., K., Tano, K., and Gnakri, D., 2009. Effects of processing method and blend on some physicochemical properties and digestibility of flours made from selected cereals and legumes. International Journal of Biology and Chemistry Science, 3(5): 1151-1160

Brou, K., N'Da-Kouassi, A., M., Kouadio, J., H., Guehi, T., N'Guessan, K., F., and Gnakri, D., 2013. Biochemical characterization and functional properties of weaning food made from cereals (millet, maize) and legumes (beans, soybeans). Journal of food chemistry and nutrition, 1(1): 22-32.

Cardinale, E., Perrier, Gros-Claude, J., D., Tall, F., Gueye, E., F., Salvat, G., 2005.
Risk factors for contamination of readyto-eat street vended poultry dishes in Dakar, Senegal. International Journal of Food Microbiology. 103, 157-165.

Clermont, O., Bonacorsi, S., and Bingen, E., 2000. Rapid and simple determination of the Escherichia coli phylogenetic group. Application of Environment Microbiology, 66: 4555-4558.

Corsetti, A., and Settanni, L., 2007. "Lactobacilli in sourdough fermentation," Food Research International, 40 (5): 539-558.

Dadié, A., Nzebo, D., Nathalie, G., Etienne, D. and Mireille, D., 2010. Prévalence de Escherichia coli entéropathogènes dans le lait non pasteurisé produit à Abidjan, Côte d'Ivoire. International Journal of Biology and Chemical Science 4(1): 1118.

Dadié, 2013. Ecosystème alimentaire et humain et diversité des Escherichia coli de 2005 à 2010 à Abidjan (Côte d'Ivoire). Thèse de doctorat d'état.

Dadié, A., Kouassi, N., Dako, E., Dje, M., and Dosso, M., 2014. Virulence, serotype and phylogenetic groups of diarrhoeagenic Escherichia coli isolated during digestive infections in Abidjan, Côte d'Ivoire. African Journal of Biotechnology, 13(9): 998-1008.

Daniels, R.,W., 1998. Home food safety. Journal of Food Technology 52, 54-56.

Dawson, P., Han, I., Cox, M., Black, C., and Simmons, L., 2006. Resident time and food contact time effects on transfer of Salmonella Typhimurium from tile, wood and carpet: Testing the five second rule. Journal of Applied Microbiology, 102(4): 1364-5072

Elenga, M., Massamba, J., Kobawila, S., C., Makosso, V., G., et Silou, T., 2009. Evaluation et amélioration de la qualité nutritionnelle des pâtes et des bouillies de maïs fermenté au Congo. International Journal of Biology and 
Chemistry Sciences, 3: 1274-1285

FAO [Food and Agriculture Organization of the United Nations], 2007. Les bonnes pratiques d'hygiène dans la préparation et la vente des aliments de rue en Afrique. Outils pour la formation. 188 p.

Feglo, P., and Sakyi, K., 2012. Bacterial contamination of street vending food in Kumasi, Ghana. Journal of Medical and Biomedical Sciences 1(1): 1-8

Fletcher, R., J., 2004. "Pseudocereals/ overview," in Encyclopedia of Grain Science, C. Wrigley, Ed., pp. 488-493, Elsevier Academic Press, Oxford, UK.

Gadaga, T., H., Nyanga, L., K., and Mutukumira, A., N., 2004. The occurrence, growth and control of pathogens in African fermented foods. African Journal of Food Agriculture Nutrition and Development, 4 (1), p 9.

Glidja, T., M., M., 2004. L'alimentation de complément chez les enfants de 6 à 12 mois dans la Commune de Bopa (Département du Mono): pratiques en usage et qualités nutritionnelle et microbiologique des aliments de complément consommés. Diplôme d'Ingénieur Agronome Option : Nutrition et Sciences Alimentaires. Université d'Abomey-Calavi.

Hanashiro, A., Morita, M., Matte, G., R., Matte, M., H., Torres, E., A., 2005. Microbiological quality of selected street foods from a restricted area of Sao Paulo city, Brazil. Journal of Food Control. 16, 439-444.

Hervé, S., and Mouquet-Rivier, C., 2004. Etude de marché des farines infantiles et compléments alimentaires en milieu urbain au Burkina Faso. Rapport d'étude réalisé dans le cadre du projet NUTRIFASO. Appui financier du Programme d'Appui Danois au développement de l'agriculture au Burkina Faso, Appui Direct aux
Opérateurs Privés. 77 p.

Islam, M., A., Ahmed, T., Faruque, A., S., G., Rahman, S., Das, S., K., Ahmed, D., Fattori, V., Clarke, R., Endtz, H., P., and Cravioto, A., 2012. Microbiological quality of complementary foods and its association with diarrhoeal morbidity and nutritional status of Bangladeshi children. European Journal of Clinical Nutrition. 66: 1242-1246

Jideani, I., A., 2012. Digitaria exilis (acha/fonio), Digitaria iburua (iburu/fonio) and Eluesine coracana (tamba/finger millet) - Nonconventional cereal grains with potentials. Scientific Research and Essays, 7 (45): 3834 -3843.

Kaneko, K., I., Hayashidani, H., Takahashi, K., Shiraki, Y., Limawongpranee, S., Ogawa, M., 1999. Bacterial contamination in the environment of food factories processing ready-to-eat fresh vegetables. Journal of Food Protection. 62, 800-804.

Kohajdová, Z., and Karovičová, J., 2007. Fermentation of cereals for specific purpose. Journal of Food and Nutrition Research, 46 (2): 51-57.

Kunene, N., F., Hastings, J., W., and Holy, von, A., 1999. Bacterial Populations Associated with a Sorghum-based Fermented Weaning Cereal. International Journal of Food Microbiology; 49: 75 - 83.

Mahon, C., R., Lehman, D., C., Manuselis, G., 2007. Text Book of Diagnostic Microbiology, $3^{\text {rd }}$ ed., Philadelphia, PA, USA.

Mensah, P., Yeboah-Manu, D., OwusuDarko, K., and Ablordey, A., 2002. Street foods in Accra, Ghana: how safe are they? Bulletin of the World Health Organization, 80:546-554

Momba, M., Malakate, V., and Theron, J., 2006. Abundance of pathogenic E. coli. $S$. typhimurium and V. cholera. Journal 
Water Health, 4 p.

Moore, C., M., Sheldon, B., W., and Jaykus, L., A., 2003. Transfer of Salmonella and Campylobacter from stainless steel to romaine lettuce. Food Protection, 66(12): 2231-2236

Motarjemi. Y., Käferstein, F., Moy, G., and Quevedo, F., 1993. Contaminated Weaning Food: A Major Risk Factor for Diarrhoea and Associated Malnutrition. Bulletin of the World Health Organisation. 71: 79-92.

Nataro, J., P., and Kaper, J., B., 1998. Diarrheagenic Escherichia coli. Clinical of Microbiology Review 11: 142-201.

Nguyen, V., H., 2008. Conditions d'utilisation d'un «cuiseur-extruder à très faible coût» pour la fabrication de farines infantiles au Vietnam. Thèse 228p version électronique

Norazah, A., Rahizan, I., Zainuldin, T., Rohani, M., Y., and Kamel, A., G., 1998. Enteropathogenic Escherichia coli in raw and cooked food. The Southeast Asian Journal of Tropical Medicine and Public; 29(1). 91-93.

Nout, M., J., R., 2009. Rich nutrition from the poorest - Cereal fermentations in Africa and Asia. Food Microbiology 26, 685692

Nyatoti, V., N., Mtero, S., S., Rukure, G., 1997. Pathogenic E. coli in traditional African weaning foods. Journal of Food Control. 8: 51-54.

Ogata, K., Kato, R., Ito, K., and Yamada, S., 2002. Prevalence of Escherichia coli possessing the eaeA gene of enteropathogenic E. coli (EPEC) or the aggR gene of enteroaggregative $E$. coli (EAggEC) in traveler's diarrhea diagnosed in those returning to Tama, Tokyo from other Asian countries. Japan Journal Infection Disease; 55(1):14-8.

Olorode, O., O., Idowu M., A., and Ilori, O., A., 2013. Effect of benoil (Moringa oleifera) leaf powder on the quality characteristics of 'Ogi'. American Journal of Food and Nutrition, 3(2): 8389.

Olorunfemi, D., I., Dede, A., P., O., and Idu, M., 2005. Production of fermented cereal powders. Natural Product Radiance. IPC Code, Int. Cl-A23L 1/10, A23L 1/105

Oluwafemi, F., Ibeh, N., I., 2011. Microbial contamination of seven major weaning foods in Nigeria. J Health Popul Nutr. 29(4):415-9.

Oumarou, D., H., Balla, A., and Barrage, M., 2012. Acceptabilité et efficacité des aliments de complément locaux proposés par les ONG au Niger. JAB., 56 (1997-5002): 4089 - 4096.

PAM (Programme Alimentaire Mondial), 2008. Rapport d'analyse de marché. Sénégal : commerce du Riz. World Food Programm.

Pether, J., V., S., and Gilbert, R., J., 1971. The survival of Salmonellas on fingertips and transfer of the organisms to food. Journal of Hygiene, 69, 673-681.

Rappelli, P., Folgosa, E., Solinas, M., L., DaCosta, J., L., Pisanu, C., Sidat, M., Melo, J., Cappuccinelli, P,. and Colombo, M,. M,. 2005. Pathogenic enteric Escherichia coli in children with and without diarrhea in Maputo, Mozambique. FEMS Immunology and Medical Microbiology 43: 67-72.

Sandel, M., K., McKillip, J., L., 2004. Virulence and recovery of Staphylococcus aureus relevant to the food industry using improvements on traditional approaches. Journal of Food Control 15, 5-10.

Scott, E., Bloomfield, S., F., and Barlow, 1982. An investigation of microbial contamination in the home. Journal of Hygiene 89, 279-293.

Simango, C., Dindiwe, J., Rukure, G., 1992. Bacterial contamination of food and 
household drinking water in a farm worker community in Zimbabwe. Journal of Tropical Medicine and Hygiene 94, 388-392.

Soro-Yao, A., A., Brou, K., Koffi-Nevry, R., and Djè, K., M., 2013. Microbiology of Ivorian fermented products: A review. Asian Journal for Agriculture and Food Sciences, 1(2): 37-47.

Soro-Yao, A., A., Brou, K., Koussémon, M., and Djè, K., M., 2014. Proximate composition and microbiological quality of millet gruels sold in Abidjan (Côte d'Ivoire). International Journal of Agriculture Innovations and Research, 2: 472-479.

Sperber, W., H., 2007. Role of microbiological guidelines in the production and commercial use of milled cereal grains: a practical approach for the $21^{\text {st }}$ century. Journal of Food Protection. 70:1041-53

Taulo, S., Wetlesen, A., Abrahamsen, R., K., Narvhus, J., A., and Mkakosya, R., 2009. Quantification and variability of Escherichia coli and Staphylococcus aureus cross-contamination during serving and consumption of cooked thick porridge in Lungwena rural households, Malawi. Food Control, 20: 1158-116.

Theron, J., Cilliers, J., Du Preez, M., Brozel, V., and Venter, S., 2000. Detection of toxigenic Vibrio cholerae from environmental water samples by an enrichment broth cultivation-pit-stop semi-nested PCR procedure. Journal of Applied Microbiology, 89: 539-546.

Tou, E., H., K-P., 2007. Caractérisation et amélioration du procédé traditionnel de préparation de la bouillie de mil fermente, ben-saalga, utilisée comme aliment de complément au Burkina Faso. Thèse Pp. 200. Online.

[TPA] Réseau de Technologie et partenariat en Agroalimentaire, 1998. Dossier «
Les farines infantiles » [Childhood flours], Bulletin du réseau TPA, $\mathrm{n}^{\circ} 15$. 211-213. French. http: //www.gret.org/gret1/gret11

Traoré, Tahirou, Zagré, Noël, M., Traoré, Alfred, S., and Trèche, S., 2003. Effet de la consommation de bouillies fortifiées de haute densité énergétique sur les ingérés, la croissance et les statuts en fer et en vitamine A d'enfants de 6 à 10 mois en zones rurales sahéliennes. 2ème Atelier international / 2nd International Workshop. Voies alimentaires d'amélioration des situations nutritionnelles. Food-based approaches for a healthy nutrition Ouagadougou, 23-28 / 11 / 2003

Trèche, S., 2002. Complementary foods in developing countries: Importance, required characteristics, constraints and potential strategies or improvement. In P. Kolsteren, \& T. Hoerée (Eds.), Proceedings of the International Colloquium promoting growth and development of under fives. Antwerpen, pp. 132-148, ITG Press. conditions. International Journal of Food Sciences and Nutrition; 52: 213-218.

WHO [World Health Organization], 1989. Health surveillance and management procedures for food handling personnel. WHO Technical Report Series, 785 Geneva p 52.

WHO [World Health Organization], 2003. Special issue based on a World Health Organization expert consultation on complementary feeding. Geneva: World Health Organization.

Wrigley, C., 2004. "Cereals/overview," in Encyclopedia of Grain Science, C. Wrigley, Ed., pp. 187-201, Elsevier Academic Press, Oxford,UK.

Yatsuyanagi, J., Saito, S., Sato, H., Miyajima, Y., Amano, K., and Enomoto, K., 2002. Characterization of enteropathogenic and enteroaggregative Escherichia coli 
isolated from diarrheal outbreaks. Journal of Clinical Microbiology, 40: 294-297.

Yeboah-Manu, D., Kpeli, G., Akyeh, M., and Bimi, L., 2010. Bacteriological quality of ready-to-eat foods sold on and around University of Ghana Campus. Research Journal of Microbiolory, 5:130-136.
Yousef, M., Alikhani, Akbar, M., Bahram, F., Mohammad, R., Pourshafie, M, and Mehdi, A., 2007. Prevalence of Enteropathogenic and Shiga Toxinproducing Escherichia coli among Children with and without Diarrhoea in Iran. Journal Health Population Nutrition. 25(1): 88-93.

\section{How to cite this article:}

Kouame N'zebo, D., A. Dadie, O.L. Anin-Atchibri, N. Kouassi and Dje, K.M. 2017. Prevalence of Enteropathogenic Escherichia coli in Maize (Zea mays) or Millet (Pennicetum glaucum) Flours and Porridges. Int.J.Curr.Microbiol.App.Sci. 6(1): 819-833. doi: http://dx.doi.org/10.20546/ijcmas.2017.601.097 